\title{
Johtoryhmän puheenvuoro tasa-arvokeskusteluun
}

Aikuiskoulutuksen nykyistä kehittämistyötä ohjaava "aikuiskoulutuksen johtoryhmä" on omaksunut toiminnassaan keskustelemaan pyrkivän etenemistavan. Niinpä johtoryhmä julkaisi viime vuoden lopulla raportin "Aikuiskoulutuksen ihmiskuva". Raportin oli laatinut johtoryhmän toimeksiannosta apulaisprofessori Tapio Vaherva Jyväskylän yliopistosta. Aikuiskasvatuslehdessä otettiin ihmiskuvaraporttiin välittömästi kantaa $(1 / 1982)$ ja sitä on arvioitu monissa eri seminaareissa ja keskustelutilaisuuksissa. Tämä keskustelu jatkuu edelleen.

Viime keväänä ilmestyi johtoryhmältä uusi raportti "Tasa-arvo aikuiskoulutuksen suunnittelun periaatteena".1) Tässä 45 sivua käsittävässä muistiossa ei mainita erikseen sen laatijan nimeä, joten se on katsottava johtoryhmän kollektiivisen työn tulokseksi.

\section{Tasa-arvoraportin asema kokonaissuunnittelussa}

Jo aikuiskoulutuskomitea piti aikuiskoulutuspolitiikan eräänä keskeisenä perustavoitteena koulutuksellisen tasa-arvon lisäämistä. Muihin perustavoitteisiin verrattuna se asetettiin erityisasemaan. Pidettiin välttämättömänä, että se ohjaa koulutuksen suunnittelua kaikessa aikuiskoulutuksessa. Komitean mukaan tasa-arvotavoite merkitsee aikuiskoulutuspolitiikassa pyrkimystä taata kaikille aikuisille samanlaiset mahdollisuudet jatkuvaan opiskeluun ja itsensä kehittämiseen.

Valtioneuvoston aikuiskoulutusta koskevassa periaatepäätöksessä vuodelta 1978 tasa-arvotavoitteelle annettiin korostettu asema. Se valittiin yhdeksi niistä neljästä kehittämisperi-

1 ) Molempia raportteja saa Kansalais- ja työväenopistojen liitosta (KTOL), Cygnaeuksenk. 4 B 10, 00100 Helsinki 10. Puh. 90-499128. Hinta á 12 $\mathrm{mk}$. aatteesta, joille koko suunnittelun tulee rakentua.

Aikuiskoulutuksen kehittämisorganisaation laatimaan aikuiskoulutuksen kehittämisen yleissuunnitelmaan kuuluu laaja ja moniosainen perusprojekti. Sen eräänä osatehtävänä on koulutuksellista tasa-arvoa lisäävien toimenpiteiden suunnittelu. Tämän tehtävän tavoitteeksi on asetettu ensinnäkin koulutuksellisen tasa-arvon käsitteen määrittely ja toiseksi esityksen tekeminen niiksi periaatteiksi ja koulutusstrategioiksi, joita koulutuksellisen tasa-arvon lisääminen aikuiskoulutuksen eri tehtäväalueilla vaatii.

Aikuiskoulutuksen johtoryhmän toimeksiannossa todetaan, että sen tehtävänä on $\mathrm{mm}$. "'koordinoida ja ohjata opetusministeriön apuna osaprojektien työtä...". Johtoryhmä on julkaissut tasa-arvomuistion juuri tässä mielessä, eli voidakseen koordinoida eri osaprojektien suunnittelua ja antaakseen toimikunnille teoreettisia aineksia niiden suunnitellessa koulutuksellisen tasa-arvon lisäämistä omilla toimintalohkoillaan ja suunnitelmissaan. Näin ollen muistiota arvioitaessa tulisi lähteä siitä, kuinka hyvin siinä on onnistuttu hahmottamaan suunnittelussa hyväksytty tasaarvolähtökohta ja kuinka hyvin eri toimikuntakuntien on mahdollista käyttää sitä apuna omassa suunnittelutyössään.

On kuitenkin huomattava, että johtoryhmä on julkaissut muistion eräänlaisena väliraporttina, jossa koulutuksellisen tasa-arvokäsitteen teoreettista määrittelyä ei ole haluttu/osattu lopullisesti muotoilla. Sillä, että itse käsitettä ja sen vaatimia toimenpiteitä pohditaan samanaikaisesti on johtoryhmän mielestä etunsa, ' koska näillä osatehtävillä on kiinteä vuorovaikutussuhde keskenään"'. 


\section{Muistion keskeinen sisältö ja johtopäätökset}

Muistion loppuun on koottu tiivistetyssä muodossa siinä esitetyt keskeisimmät näkökohdat ja johtopäätökset. Ne ovat seuraavat:

Niita tasa-arvon tulkintoja, joita kaytetädn varsinaisen koulujarjestelmän puolella, ei voida sellaisenaan siirtdd aikuiskoulutuksessa sovellettaviksi, koska ndiden toimintajarjestelmien lahtökohdat ovat olennaisesti toisistaan poikkeavat.

$\square$ Aikuiskoulutuksen tasa-arvopolitiikan perustana on yksilön oma arvojarjestelma ja normisto, jotka saattavat ja saavat olla ristiriidassa yhteiskunnan vastaavien jurjestelmien ja normistojen kanssa, seka yhteiskunnan madrittelemä käsitys tasa-arvosta. Mikali nämä kaksi perustaa ovat keskenadan ristiriidassa, on koulutuksen otettava lahtökohdakseen yksilön arvojurjestelmä ja normisto. Näiden kahden eri lahtökohtamahdollisuuden tiedostaminen suunnittelussa on valttamatöntà, koska ne johtavat erilaisiin koulutusstrategioihin.

Koulutuksen suunnittelussa ei voi suoranaisesti vaikuttaa yhteiskuntapolitiikan muilla alueilla tehtdviin ratkaisuihin. Kuitenkin vahinta, mitd tulee tehdd, on osoittaa ne muilla yhteiskuntapolitiikan aloilla olevat epdkohdat, joiden poistaminen on sivistyksellisen yhdenvertaisuuden toteutumisen ehto. Sen lisaksi on hakeuduttava tdhänastista kiintedmpadn yhteistyöhön yhteiskuntapolitiikan eri sektoreiden kesken koulutukseen liittyvien tehtdvien kokonaisvaltaiseksi suorittamiseksi.

Koulutuksen suunnittelijaa ohjaa aina tietoisesti tai tiedostamatta jokin kuva ihmisestä ja yhteiskunnasta. Tasa-arvopolitiikan onnistumisen erdand perusedellytyksend on se, etta suunnittelulle pohjaa luova ihmiskuva on riittavan selvästi tiedostettu ja sen keskeiset ainekset ilmi lausuttu. Muussa tapauksessa tehdyt ratkaisut ovat sattumanvaraisia, ja ne voivat johtaa jopa koulutuksellisen eriarvoisuuden lisddntymiseen. Koulutuksellista tasa-arvoa ei voida lisatd ilman, ettd siihen madratietoisesti pyritadn.

Avainongelmaksi muodostuu usein se, miten deprivoituneet tai muuten passiiviset ihmiset ja ryhmat saadaan tiedostamaan omat kehittymismahdollisuutensa ja -tarpeensa. Tahan tiedostamiseen voidaan pyrkid mm. siten, etta koulutuksessa ja muissa sivistyksellisesti aktivoivissa toiminnoissa tarjotaan mahdollisuus arvojen ja asenteiden syvalliseen kokemiseen. Tässä tarkoituksessa tulee voimakkaasti tukea kansalaisten omaehtoisia sivistyksellisid pyrkimyksid omien pienyhteisöjensd kehittamiseksi.

Koulutuksellista tasa-arvoa on tahan asti pyritty lisadmadan padasiassa parantamalla koulutustarjontaa. Erityisesti ammatillisen koulutuksen tarjontaa on edelleenkin kehitettdvd, mutta on korostettava myös sitd, ettd tarvitaan muitakin toimenpiteita pelkka palvelujen madran lisadminen ei $y k$ sin riitd.

Paras tulos voidaan saavuttaa yhdistamalla erilaatuisia toimenpiteita. Tamä edellyttda

- asenteisiin vaikuttamista,

- tiedottavan ja muun opintoneuvonnallisen toiminnan lisadmista,

- opetustavoitteiden ja -sisältöjen sekä työtapojen tarkistamista,

- opintososiaalisten esteiden poistamista sekd

- muiden esteiden minimoimista.

Toivotun tuloksen kannalta on valttamatönta, etta toimenpiteet kohdistetaan strategisesti oikeisiin aikuisryhmiin ja ettd toimintoja kehitetadn aikuisten elamantilanteesta ja tarpeista lahtien.

Deprivoituneen tai muutoin passiivisen ihmisen maailma ei ole 'hallinnonaloittain järjestyksessa'. Sen lisaksi hän saattaa tuntea suoranaista pelkoa koulutusta ja sen edellyttamid formaliteetteja kohtaan. Tdmän vuoksi tulisi haivyttad tai ainakin madaltaa koulutuksen ja muiden sivistyksellisten toimintojen vallisid raja-aitoja. Koulutuksen ja muun yhteiskunnan vuorovaikutusta on lisattdva. Aikuiskoulutuksen tehtavand ei ole pelkastadn toteuttaa yhteiskuntapolitiikan tavoitteita, vaan myös vaikuttaa niihin.

Suunnitteluperiaatteena tasa-arvo ulottuu kaikille aikuiskoulutuksen tehtdvdalueille. Sen sovellukset vaihtelevat kuitenkin suuresti tehtdvdalueittain, jopa saman tehtdvaalueen sisallakin.

Yhteiskunnalla on eettinen velvoite vahiten koulutettuja kohtaan. Taman lisaksi sen on tarkoituksenmukaista hyodyntdd kaikki ne lahjakkuusreservit, joihin voidaan vielä aikuiskoulutuksen valityksella vaikuttaa. Vain yksilo, jolla on ollut mahdollisuuksia kehittdd itseddn, voi olla tuottava, luova ja onnellinen sekd kasvaa omien mahdollisuuksiensa mittaan.

Koulutuksellisen tasa-arvon toteuttaminen saattaa vaatia sita, ettd oppijalle on luotava halu oppimiseen. Yhteiskunnalla ja hänelld itselladn saattaa olla kuljettavanaan pitkd ja vaikea tie, mutta maailmanlaajuiset ongelmat vaativat kaikkien inhimillisten voimavarojen kàttöa ja kehittamista. 